\title{
Risk Factors for Fungal Co-Infections in Critically Ill COVID-19 Patients, with a Focus on Immunosuppressants
}

\author{
Obinna T. Ezeokoli $\mathbb{D}^{\text {, Onele Gcilitshana and Carolina H. Pohl * }}$ \\ Yeast Research Group, Department of Microbiology and Biochemistry, University of the Free State, \\ Bloemfontein 9300, South Africa; 2019875893@ufs4life.ac.za or ezeokoliobinna@gmail.com (O.T.E.); \\ GcilitshanaOMN@ufs.ac.za (O.G.) \\ * Correspondence: PohlCH@ufs.ac.za
}

check for updates

Citation: Ezeokoli, O.T.; Gcilitshana, O.; Pohl, C.H. Risk Factors for Fungal Co-Infections in Critically Ill COVID-19 Patients, with a Focus on Immunosuppressants. J. Fungi 2021, 7, 545. https://doi.org/10.3390/jof 7070545

Academic Editor: David S. Perlin

Received: 24 May 2021

Accepted: 29 June 2021

Published: 9 July 2021

Publisher's Note: MDPI stays neutral with regard to jurisdictional claims in published maps and institutional affiliations.

Copyright: (c) 2021 by the authors. Licensee MDPI, Basel, Switzerland. This article is an open access article distributed under the terms and conditions of the Creative Commons Attribution (CC BY) license (https:// creativecommons.org/licenses/by/ $4.0 /)$.

\begin{abstract}
Severe cases of coronavirus disease 2019 (COVID-19) managed in the intensive care unit are prone to complications, including secondary infections with opportunistic fungal pathogens. Systemic fungal co-infections in hospitalized COVID-19 patients may exacerbate COVID-19 disease severity, hamper treatment effectiveness and increase mortality. Here, we reiterate the role of fungal co-infections in exacerbating COVID-19 disease severity as well as highlight emerging trends related to fungal disease burden in COVID-19 patients. Furthermore, we provide perspectives on the risk factors for fungal co-infections in hospitalized COVID-19 patients and highlight the potential role of prolonged immunomodulatory treatments in driving fungal co-infections, including COVID-19-associated pulmonary aspergillosis (CAPA), COVID-19-associated candidiasis (CAC) and mucormycosis. We reiterate the need for early diagnosis of suspected COVID-19-associated systemic mycoses in the hospital setting.
\end{abstract}

Keywords: COVID-19; fungal co-infections; corticosteroid treatment; COVID-19-associated candidiasis; COVID-19-associated pulmonary aspergillosis; mucormycosis

\section{Introduction}

The current COVID-19 disease has infected over 180 million people worldwide, with associated deaths in upwards of 3.9 million [1]. The disease is characterized by a variety of symptoms, of which breathing difficulties are typical of severe cases [2]. Such severe cases require urgent intervention in hospitals, including oxygenation and mechanical ventilation. For such patients, a variety of other complications may arise, including hospitalacquired secondary infections with opportunistic pathogens, including molds and yeast infections. In the current severe acute respiratory syndrome-coronavirus-2 (SARS-CoV-2) pandemic, fungal co-infections among COVID-19 patients in intensive care units (ICUs) has been reported [3-7]. White et al. [7] reported an incidence of $14.1 \%$ and $12.6 \%$ for aspergillosis and yeast infections, respectively, amongst critically ill COVID-19 patients across multiple centers in Wales. Bartoletti et al. [6] reported a higher incidence of $27.7 \%$ for invasive pulmonary aspergillosis (IPA) (or COVID-19-associated pulmonary aspergillosis, CAPA) amongst COVID-19 patients (of a 108 patient cohort) requiring invasive mechanical ventilation between late February and April 2020 in Italy. Based on analysis of clinical data from several countries, Salmanton-Garcia et al. [5] found that the aggregate incidence of CAPA was between $1 \%$ and $39.1 \%$ amongst COVID-19 patients in ICUs. Apart from CAPA, the incidence of candidemia has also been reported among hospitalized COVID-19 patients, with up to $12 \%(106 / 889)$ reported for one health center [8] and between $1.54 \%$ and $7.54 \%$ for a hospital in Rio de Janeiro, Brazil [9]. Indeed, the observations of fungal co-infections, especially IPA, are not entirely unexpected in the current SARS-CoV-2 outbreak, given that similar observations were made during previous outbreaks of other coronaviruses such as the severe acute respiratory syndrome-coronavirus (SARS-CoV) and the middle east respiratory syndrome coronavirus (MERS-CoV) [10-12]. 
In order to elucidate the diversity and co-occurrence of fungal co-infections in COVID-19 patients, we summarized several randomly selected reports on fungal coinfections in COVID-19 patients (Figure 1). These reports span all but one of the inhabited continents, Africa, where to the best of our knowledge, little or no reports of fungal coinfections in critically ill COVID-19 patients currently exists. Based on our non-exhaustive summary of literature reports, at least 20 different fungal species have been reported in hospitalized COVID-19 patients. The majority of fungal co-infections are due to Aspergillus fumigatus (most common etiological agent of CAPA), followed by Candida albicans (common etiological agent of candidiasis or candidemia) (Figure 1a). Furthermore, we observed significant co-occurrences of Candida albicans and other fungal pathogens such as Aspergillus fumigatus, A. flavus and A. penicillioides amongst the reports (Figure 1b).

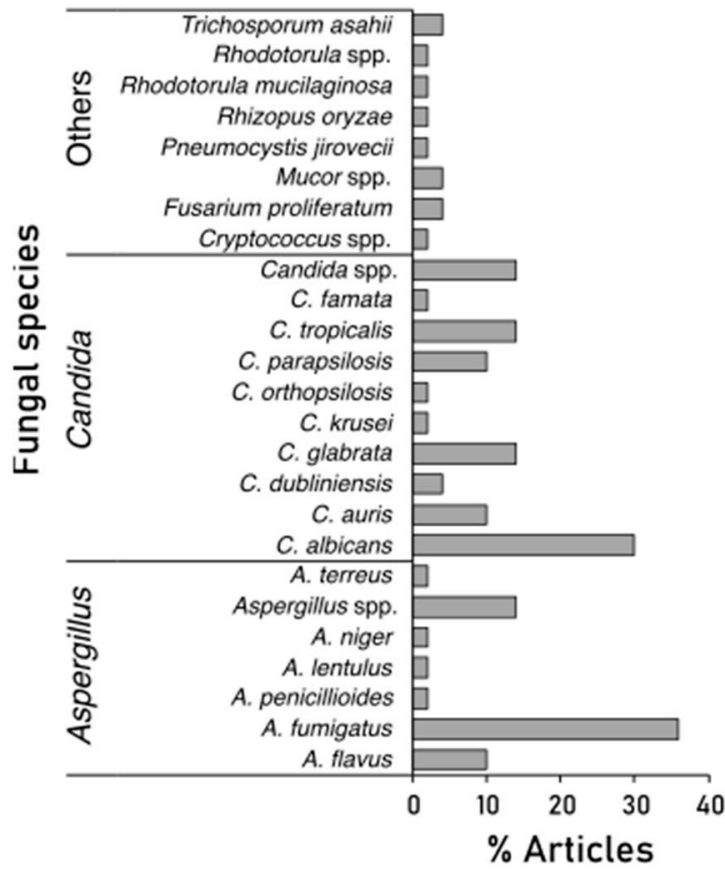

(a)

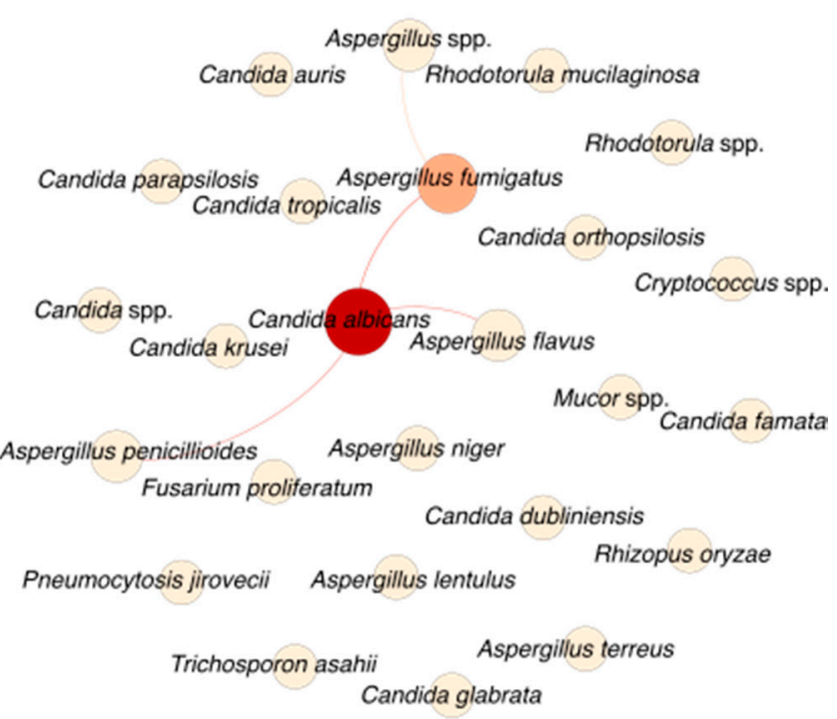

(b)

Figure 1. Distribution (a) and co-occurrence (b) of fungal species across randomly selected 50 case studies, prospective and retrospective published reports on fungal co-infections in hospitalized COVID-19 patients [5,7,9,13-56] (also see Supplementary Table S1). Searches were done on PubMed (Medline) and Google Scholar using query terms such as "Co-infections", "coinfections", "fungi" or "Fungal infections" in combination with either "COVID-19" or "SARS-CoV-2". Most ( $>50 \%$ ) of the selected articles included cases from the onset of the COVID-19 pandemic in several countries (December 2019-April 2020). In the co-occurrence network, nodes are colored based on betweenness centrality (species with high co-occurrence), while edges (connecting lines) indicate significant $(p<0.05)$ co-occurrence between species. The network was constructed using the visNetwork package of R (https:/ /cran.r-project.org/web/packages/visNetwork/index.html, accessed on 21 May 2021) and further annotated in Gephi (https://gephi.org/, accessed on 21 May 2021).

In this review, we reiterate the role of fungal co-infections in exacerbating COVID-19 disease severity as well as highlight emerging trends related to fungal disease burden and multidrug resistance in COVID-19 patients. In particular, we provide up to date perspective on the risk factors for systemic mycoses in hospitalized patients with a specific focus on the potential role of immunomodulatory and/or immunosuppressive drugs in driving the observed high prevalence of fungal co-infections in COVID-19 patients in the ICU. 


\section{Fungal Co-Infections in COVID-19 Disease: Disease Severity, the Emergence of Multidrug Resistance and Mucormycosis}

\subsection{Contribution to COVID-19 Disease Severity and Mortality}

Prospective and retrospective data of COVID-19 patients admitted to intensive care units (ICU), especially for a prolonged duration, show that these patients are susceptible to invasive microbial co-infections during hospitalization and that these may lead to more severe outcomes [3,7,16,31]. A prospective cohort study of 135 adults, performed across multiple centers in Wales, showed a significantly higher (up to $25 \%$ ) mortality rate in COVID-19 patients with fungal infections compared to patients without fungal infections [7]. In particular, a multicenter study of 108 COVID-19 patients admitted to the ICUs in Italy showed a significantly higher 30-day mortality rate for patients with probable COVID-19-associated pulmonary aspergillosis (CAPA) or putative invasive pulmonary aspergillosis, compared to patients without suspected aspergillosis [6]. Similarly, Meijer et al. [38] reported mortality between $40 \%$ and $50 \%$ in patients with CAPA across the first wave (March-April 2020) and second wave (mid-September to mid-December 2020) of the COVID-19 pandemic in Brazil.

With respect to COVID-19-associated candidiasis (CAC), although the incidence rates may be slightly lower than that of CAPA, the mortality rate of COVID-19 patients with candidemia do not appear to differ markedly. Reports from Italy indicate that up to $57.1 \%$ and 50\% mortality was reported in COVID-19 patients with candidemia [57] and Candida auris candidemia [27], respectively. Elsewhere, the mortality rate of COVID-19 patients with candidemia exceeded those of counterparts without candidemia in Iran $(100 \%$ vs. $22.7 \%$ ) [31]. Altogether, these observations highlight and re-emphasize the propensity of fungal co-infections to exacerbate disease severity and, consequently, increase the mortality of critically ill patients admitted to the ICUs.

\subsection{Emergence of Multidrug-Resistant Fungi}

Another concerning development is the report of the incidence of multidrug-resistant Aspergillus fumigatus [56] and Candida auris [26,27,58], as well as pan-echinocandin resistant C. glabrata amongst COVID-19 patients [59]. C. auris is a multidrug-resistant fungal pathogen that causes life-threatening systemic infections and could have a 30-day mortality rate of up to 35\% [60-62] and a report from India stated a case-fatality rate of $60 \%$ amongst COVID-19 patients with candidemia due to multidrug-resistant $C$. auris infection [26]. Managing candidemia outbreaks due to $C$. auris poses a great challenge due to its resistance to multiple drugs and persistence in the human body and environment $[63,64]$. Suarez-dela-Rica et al. [65] observed that co-infections by antimicrobial-resistant pathogens might be consequential for COVID-19 prognosis. In their study, the hazard ratio for death within 90 days in critically ill COVID-19 patients was significantly increased by antimicrobialresistant pathogens. Hence, given that antifungal resistance undermines treatment efforts and can escalate treatment costs, such reports of multidrug resistance to antifungals, including echinocandins, are worrying. Furthermore, these reports highlight the need to appreciate the global burden of fungal co-infections in the current COVID-19 pandemic and the importance of prompt diagnosis and treatment of fungal pathogens in hospitalized COVID-19 patients.

\subsection{Incidence of Mucormycosis}

Recent reports emanating from India indicate the incidence of mucormycosis mostly among COVID-19 survivors (although cases in currently hospitalized COVID-19 patients have also been observed) [66-69]. Mucormycosis is a rare infection caused by filamentous fungi (molds) of the order Mucorales and can be fatal if the fungus penetrates the central nervous system $[70,71]$. According to one study, Rhizopus arrhizus is currently the most common etiological agent of COVID-19-associated mucormycosis (CAM) in India, with Rhizopus microsporus, Rhizopus homothallicus, Mucor irregularis, Saksenaea erythrospora and Apophysomyces variabilis also implicated in some cases in India and elsewhere [72-74]. Mu- 
cormycosis infections are common in diabetic or immunocompromised patients, including persons receiving immunosuppressive therapy [71,75]. A recent systematic review of mucormycosis cases in India and worldwide reported that corticosteroid use was recorded in $76.3 \%$ of cases and that $30.7 \%$ of mucormycosis cases were fatal [76]. Thus far, it is unclear whether the incidence of CAM is worldwide, and research is needed in this regard. Altogether, the foregoing reports and several other studies suggest that the heightened incidence of mucormycosis in India are related to certain risk factors, including poorly managed diabetes and the prolonged usage of high dosage steroids in treating COVID-19 [69,77,78].

\section{Overview of Risk Factors for Opportunistic Fungal Infections in Critically Ill COVID-19 Patients}

Overall, risk factors driving the high incidence of aspergillosis and candidemia in COVID-19 patients are related to invasive procedures (e.g., intubation) predisposing lung tissues to fungal colonization and proliferation [79-81], history of chronic pulmonary disease [7], prolonged corticosteroid treatments [7,82], immunological disposition of patients and antimicrobial therapy $[59,64]$. In one study comparing co-infections in critically ill patients with and without COVID-19, it was observed that the need for invasive assisted respiration was the most decisive factor for co-infections with antifungal-resistant pathogens in patients with severe COVID-19 [79]. In the following subsections, we provide an overview of risk factors associated with CAPA and CAC - the two most commonly reported fungal co-infections in hospitalized COVID-19 patients.

\subsection{Risk Factors for CAPA}

Given the high incidence of CAPA and the distinct clinical features of CAPA compared to influenza-associated pulmonary aspergillosis, it has been necessary to establish appropriate case definitions for CAPA in order to facilitate uniformity of reporting across medical practices. To this end, a number of case definitions or guidelines have been proposed for characterizing possible, putative, probable and proven CAPA cases $[7,83,84]$ (case definitions for CAPA is not within the purview of this review). CAPA is essentially defined as pulmonary or tracheobronchial infection with Aspergillus spp. in COVID-19 patients. In one proposed case definition by Koehler et al. [83], a proven case of CAPA may be established by direct microscopic and/or histopathological evidence of fungal features that are typical of Aspergillus spp. Such evidence includes an observation of invasive growth into tissues with concomitant tissue damage, recovery of Aspergillus spp. by culture, detection of Aspergillus by microscopy in histology studies or by polymerase chain reaction from materials obtained by sterile aspiration or biopsies from a pulmonary site indicating an infectious disease.

Several factors predispose hospitalized COVID-19 patients to CAPA. SARS-CoV-2 insults in the lungs elicit the release of danger-associated molecular patterns (DAMPs) in severe COVID-19 [80]. Essentially, DAMPs are host-derived molecules that regulate the activation of pathogen recognition receptors and modulate the host's organ response to injury [85]. The release of DAMPs is accompanied by inflammation and extensive damage of lung epithelial tissues, which are enabling risk factors for invasive pulmonary aspergillosis [80]. Other pathophysiological factors identified for IPA and potentially CAPA, include an impaired local immune response and a dysfunctional defective mucociliary activity [12,50]. In severe COVID-19 disease, extensive inflammation and injury to the lungs lead to acute respiratory syndrome (ARDS). ARDS is characterized by difficulty in breathing; hence, assisted ventilation is required for such patients. However, mechanical ventilation and the duration of ventilation is a known risk factor for invasive aspergillosis and CAPA in the ICU $[50,86,87]$.

In addition, pharmaceutical treatments for malignancy and the use of corticosteroids (discussed in a later section) and antibiotics may be risk factors for CAPA [7,88]. For example, in a multicenter study across Wales [7], a significant association was observed between COVID-19 patients with IPA and patients treated for or diagnosed with solid malignancy. Further, in a multilocation retrospective cohort conducted in France, Dellière et al. [88] 
reported that treatment with azithromycin for up to 3 days significantly correlated with the incidence of probable invasive pulmonary aspergillosis in COVID-19 patients. Such observation was attributed to the immunomodulatory properties of azithromycin that may weaken the host's immune response and subsequent susceptibility to aspergillosis [88,89].

\subsection{Risk Factors for $C A C$}

COVID-19-associated candidiasis (CAC) refers to the detection of one or more Candida spp. in the bloodstream or body tissues of COVID-19 patients. As earlier indicated, Candida albicans and other non-albicans Candida species have been reported among hospitalized COVID-19 patients $[9,29,57,81]$. Some of the risk factors identified for CAC include prolonged hospital stays, mechanical ventilation, central venous catheters, surgical procedure, and the use of broad-spectrum antibiotics [9,29]. For example, Nucci et al. [9] observed that COVID-19 patients with candidemia were more likely to be under mechanical ventilation than non-COVID-19 patients. Similarly, Mastrangelo et al. [57] reported that COVID-19 patients with candidemia were more likely to be in the ICU and receiving immunosuppressive agents than patients in the ICU for reasons other than COVID-19. In another report, the development of pan-echinocandin resistant C. glabarata co-infections in a hospitalized 53-year-old COVID-19 patient potentially rendered antifungal treatment ineffective and probably aggravated the progression of the disease [59]. According to the authors, the case report demonstrated the need for active monitoring for antifungal resistance development in order to inform the dynamic use of effective antifungal agents during patient management in the intensive care unit.

\section{Immunosuppressants as Risk Factors for Fungal Infections in Critically Ill COVID-19 Patients}

Most of the current treatment options for managing patients with severe COVID-19 are immunomodulators [90]. The anti-inflammatory properties of these immunomodulators are important to counteract the heightened and unregulated release of pro-inflammatory cytokines (also known as 'cytokine storm') in the lungs during SARS-CoV-2 infection [91,92]. Thus, immunosuppressants such as dexamethasone, methylprednisolone, prednisone, hydrocortisone and tocilizumab constitute the most common treatment options for managing severe COVID-19 cases in the ICU [90]. From a COVID-19 treatment standpoint, immunostimulants are required during the early stages of the disease, whereas immunosuppressants may be more beneficial to dampen the cytokine storm in the later stages of the disease [93]. For example, dexamethasone treatment decreased the 28-day mortality in COVID-19 patients on invasive respiratory support or receiving oxygen alone but was not particularly beneficial for COVID-19 patients with less severe disease, suggesting that hyper inflammation mediates the advanced stage of the disease and therefore can be alleviated by immunosuppressants $[93,94]$.

Unfortunately, the immunosuppressants hamper both the individual's innate and adaptive immune responses through sophisticated quantitative and qualitative mechanisms of immune deregulation [88,95-98], thereby increasing patients' susceptibility to invasive fungal diseases. In particular, steroidal immunosuppressants such as corticosteroids predominantly affect the protective immunity process qualitatively through functional impairment of several effector immune cells, such as monocytes, polymorphonuclear leukocytes, T lymphocytes and macrophages [96] and is a significant acquired immunological risk factor for pulmonary aspergillosis $[99,100]$. Thus, corticosteroids such as dexamethasone and methylprednisolone, used for managing critically ill COVID-19 patients, have contraindications, including fostering secondary microbial infections in patients [99,101].

In the present COVID-19 pandemic, questions are being asked regarding the possible relationship between immunosuppressant or corticosteroid use and the incidence of fungal infections in critically ill COVID-19 patients (Table 1). A prospective study conducted across multiple COVID-19 intensive care units in Wales showed that the use of high-dose systemic corticosteroids significantly increased the odds of COVID-19 patients developing aspergillosis [7]. Similarly, in Brazil, Riche et al. [82] observed a 10-fold increase in 
candidemia amongst a cohort of critically ill COVID-19 patients receiving high doses of corticosteroids such as prednisone, hydrocortisone, methylprednisolone and dexamethasone, while a retrospective study conducted in Chicago and involving 111 COVID-19 patients receiving tocilizumab (a monoclonal antibody that inhibits binding of IL-6 to the membrane and soluble receptors [102]) was significantly linked with the risk of developing fungal pneumonia and sinusitis [103]. However, in a retrospective study involving 4313 COVID-19 patients in New York, corticosteroid use was not associated with increased bacteremia or fungaemia compared to non-corticosteroid users when administered within the first seven days of admission [104]. In this study, the early administration of low dose corticosteroids is advocated. It must, however, be noted that in many of the other reports, mention is made of high doses of corticosteroids often administered for prolonged periods [30], which may explain the high incidence of systemic fungal infections and ultimately negate the lifesaving benefits of these drugs. 
Table 1. Summary of literature on potential links between immunosuppressants and fungal co-infections in severely ill COVID-19 patients.

\begin{tabular}{|c|c|c|c|c|c|c|c|}
\hline Study Type & City, Country & Cohort Size & $\begin{array}{l}\text { Immunosuppressants } \\
\text { Therapy for COVID-19 }\end{array}$ & $\begin{array}{l}\text { Associated Fungal } \\
\text { Infection/Species }\end{array}$ & $\begin{array}{l}\text { Observation with } \\
\text { Regards to } \\
\text { Corticosteroid Use }\end{array}$ & $\begin{array}{l}\text { Comorbidities and } \\
\text { Other Risk Factors }\end{array}$ & Reference \\
\hline Case series & Salvador, Brazil & 2 & Unspecified & Candida auris & $\begin{array}{l}\text { Prolonged corticosteroid } \\
\text { therapy ( } 34 \text { days) }\end{array}$ & $\begin{array}{c}\text { Deep-seated venous } \\
\text { thrombosis (Patient 1); } \\
\text { Chronic renal } \\
\text { insufficiency and } \\
\text { dialysis, diabetes } \\
\text { mellitus, and } \\
\text { hypertension (Patient 2) }\end{array}$ & de Almeida [30] \\
\hline Case series & Nuevo Leon, Mexico & 12 & $\begin{array}{l}\text { Hydrocortisone, } \\
\text { methylprednisolone, } \\
\text { dexamethasone }\end{array}$ & C. auris & $\begin{array}{l}\text { Corticosteroid } \\
\text { treatments preceded the } \\
\text { onset of } C \text {. auris infection. } \\
\text { Association not } \\
\text { particularly investigated }\end{array}$ & $\begin{array}{l}\text { Obesity, asthma, high } \\
\text { blood pressure, diabetes, } \\
\text { coronary artery disease; } \\
\text { valvular heart disease }\end{array}$ & $\begin{array}{c}\text { Villanueva-Lozano } \\
\text { et al. [25] }\end{array}$ \\
\hline $\begin{array}{l}\text { Case series } \\
\text { (retrospective) }\end{array}$ & Porto Alegre, Brazil & 11 & $\begin{array}{c}\text { Prednisone, } \\
\text { hydrocortisone, } \\
\text { methylprednisolone, } \\
\text { dexamethasone }\end{array}$ & $\begin{array}{l}\text { Candidemia } \\
\text { (Candida spp.) }\end{array}$ & $\begin{array}{c}\text { All cases of } \\
\text { candidemia (a 10-fold } \\
\text { increase in frequency) in } \\
\text { COVID-19 patients } \\
\text { occurred after the use of } \\
\text { high-doses } \\
\text { of corticosteroids }\end{array}$ & $\begin{array}{l}\text { Diabetes, HIV-positive, } \\
\text { central venous catheters. } \\
\text { Additional risk factors } \\
\text { for candidemia were } \\
\text { virtually absent }\end{array}$ & Riche et al. [82] \\
\hline Prospective study & Madrid, Spain & 8 & Not specified & $\begin{array}{l}\text { Aspergillosis } \\
\text { (A.fumigatus) }\end{array}$ & $\begin{array}{l}\text { Aspergillosis affected } \\
\text { mostly }(75 \%) \text { non- } \\
\text { immunocompromised } \\
\text { COVID-19 patients } \\
\text { receiving corticosteroids }\end{array}$ & $\begin{array}{c}\text { Obesity, HTA, COPD, } \\
\text { CKD, diabetes mellitus; } \\
\text { Mostly (75\%) non- } \\
\text { immunocompromised } \\
\text { patients }\end{array}$ & Machado et al. [105] \\
\hline $\begin{array}{l}\text { Prospective } \\
\text { cohort }\end{array}$ & Milan, Italy & 21 & $\begin{array}{c}\text { Prednisone, } \\
\text { immunomodulators } \\
\text { (tocilizumab, } \\
\text { mavrilimumab, anakinra, } \\
\text { reparixin, and sarilumab) } \\
\text { and immunosuppressants } \\
\text { (tacrolimus, } \\
\text { cyclophosphamide and } \\
\text { mycophenolate) }\end{array}$ & $\begin{array}{l}\text { Candidemia (Candida } \\
\text { albicans, Candida spp.) }\end{array}$ & $\begin{array}{l}\text { A higher proportion of } \\
\text { candidemia present in } \\
\text { COVID-19 patients in the } \\
\text { ICU and on } \\
\text { immunosuppressive } \\
\text { agents }\end{array}$ & $\begin{array}{c}\text { Diabetes, } \\
\text { broad-spectrum } \\
\text { antibiotics, HIV, etc. }\end{array}$ & $\begin{array}{c}\text { Mastrangelo et al. } \\
{[57]}\end{array}$ \\
\hline
\end{tabular}


Table 1. Cont.

\begin{tabular}{|c|c|c|c|c|c|c|c|}
\hline Study Type & City, Country & Cohort Size & $\begin{array}{l}\text { Immunosuppressants } \\
\text { Therapy for COVID-19 }\end{array}$ & $\begin{array}{l}\text { Associated Fungal } \\
\text { Infection/Species }\end{array}$ & $\begin{array}{l}\text { Observation with } \\
\text { Regards to } \\
\text { Corticosteroid Use }\end{array}$ & $\begin{array}{l}\text { Comorbidities and } \\
\text { Other Risk Factors }\end{array}$ & Reference \\
\hline Prospective & Milan, Italy & 43 & Tocilizumab & $\begin{array}{l}\text { Candidemia }(C . \\
\text { albicans, C. tropicalis, } \\
\text { C. parapsilosis) }\end{array}$ & $\begin{array}{l}6.9 \% \text { prevalence of } \\
\text { candidemia observed }\end{array}$ & $\begin{array}{c}\text { Previous hospitalisation } \\
\text { in ICU; central venous } \\
\text { catheter }\end{array}$ & Antinori et al. [34] \\
\hline Case series & Puducherry, India & 10 & Dexamethasone & $\begin{array}{c}\text { Orbital } \\
\text { mucormycosis } \\
\text { (Mucor spp. and } \\
\text { Rhizopus spp.) }\end{array}$ & $\begin{array}{l}\text { Five patients developed } \\
\text { diabetic ketoacidosis } \\
\text { after the initiation of } \\
\text { corticosteroid therapy for } \\
\text { COVID-19 disease }\end{array}$ & Diabetes mellitus & Sarkar et al. [72] \\
\hline Case study & Udine, Italy & 1 & $\begin{array}{l}\text { Dexamethasone, } \\
\text { tocilizumab }\end{array}$ & $\begin{array}{l}\text { Pulmonary } \\
\text { aspergillosis }(A . \\
\text { fumigatus) }\end{array}$ & $\begin{array}{l}\text { A. fumigatus was isolated } \\
22 \text { days after tocilizumab } \\
\text { administration }\end{array}$ & $\begin{array}{c}\text { HBV-related liver } \\
\text { cirrhosis, arterial } \\
\text { hypertension and mild } \\
\text { obesity }\end{array}$ & Deana et al. [106] \\
\hline Case study & Brazil & 23 & $\begin{array}{l}\text { Methylprednisolone, } \\
\text { prednisone }\end{array}$ & $\begin{array}{l}\text { Candidemia (C. } \\
\text { parapsilosis, } C . \\
\text { tropicalis) and } \\
\text { Trichosporon asahii } \\
\text { fungemia }\end{array}$ & $\begin{array}{l}\text { Fungemia was observed } \\
\text { in all patients with a } \\
\text { history of prolonged } \\
\text { corticosteroid therapy }\end{array}$ & $\begin{array}{l}\text { CVC, exposure to } \\
\text { broad-spectrum } \\
\text { antibiotics, prior } \\
\text { echinocandin therapy, } \\
\text { obesity, diabetes }\end{array}$ & de Almeida Jr [46] \\
\hline Case series & Paris, France & 145 & $\begin{array}{l}\text { Tocilizumab, sarilumab, } \\
\text { hydrocortisone succinate }\end{array}$ & $\begin{array}{l}\text { IPMI (A. fumigatus; } \\
\text { Fusarium proliferatum) }\end{array}$ & $\begin{array}{l}\text { Corticosteroid therapies } \\
\text { were related to an } \\
\text { increased risk for } \\
\text { developing IPMI (odds } \\
\text { ratio, 8.55; IQR, 6.8-10.3; } \\
\quad p=0.01 \text { ) }\end{array}$ & $\begin{array}{c}\text { HTA, } \\
\text { overweight/obesity, } \\
\text { diabetes mellitus, COPD. } \\
\text { Solid } \\
\text { organ transplantation } \\
\text { was related to an } \\
\text { increased risk for IPMI }\end{array}$ & Fekkar et al. [107] \\
\hline Prospective & Wales, UK & 135 & $\begin{array}{c}\text { Prednisolone, } \\
\text { methylprednisolone, } \\
\text { hydrocortisone, } \\
\text { dexamethasone, } \\
\text { fludrocortisone }\end{array}$ & $\begin{array}{l}\text { Aspergillosis, yeast } \\
\text { infections (mainly } \\
\text { Candida, one case of } \\
\text { Rhodotorula } \\
\text { fungaemia) }\end{array}$ & $\begin{array}{l}\text { High-dose corticosteroid } \\
\text { use increased the } \\
\text { likelihood of } \\
\text { aspergillosis }\end{array}$ & $\begin{array}{c}\text { Previous chronic } \\
\text { respiratory disease also } \\
\text { linked to aspergillosis. } \\
\text { Associations between } \\
\text { comorbidities } \\
\text { /underlying conditions } \\
\text { and yeast infections were } \\
\text { not significant }\end{array}$ & White et al. [7] \\
\hline
\end{tabular}


Table 1. Cont.

\begin{tabular}{|c|c|c|c|c|c|c|c|}
\hline Study Type & City, Country & Cohort Size & $\begin{array}{l}\text { Immunosuppressants } \\
\text { Therapy for COVID-19 }\end{array}$ & $\begin{array}{l}\text { Associated Fungal } \\
\text { Infection/Species }\end{array}$ & $\begin{array}{l}\text { Observation with } \\
\quad \text { Regards to } \\
\text { Corticosteroid Use }\end{array}$ & $\begin{array}{l}\text { Comorbidities and } \\
\text { Other Risk Factors }\end{array}$ & Reference \\
\hline Retrospective & New York, USA & 4313 & $\begin{array}{c}\text { Methylprednisolone, } \\
\text { prednisone, } \\
\text { dexamethasone, } \\
\text { hydrocortisone }\end{array}$ & Not reported & $\begin{array}{l}\text { Corticosteroid use was } \\
\text { not associated with } \\
\text { increased bacteraemia or } \\
\text { fungaemia compared to } \\
\text { non-corticosteroid users } \\
\text { when administered } \\
\text { within the first } 7 \text { days }\end{array}$ & $\begin{array}{l}\text { Hypertension, diabetes, } \\
\text { CKD, asthma, COPD }\end{array}$ & Ho et al. [104] \\
\hline $\begin{array}{l}\text { Retrospective } \\
\text { cohort study }\end{array}$ & Paris, France & 21 & Dexamethasone & $\begin{array}{c}\text { Aspergillosis } \\
\text { (Aspergillus spp.) }\end{array}$ & $\begin{array}{l}\text { Although not statistically } \\
\text { significant, a trend was } \\
\text { observed between } \\
\text { high-dose }(\geq 100 \mathrm{mg}) \\
\text { dexamethasone and } \\
\text { incidence of IPA }\end{array}$ & $\begin{array}{l}\text { Medical history did not } \\
\text { significantly affect IPA }\end{array}$ & Dellière et al. [88] \\
\hline Retrospective & India & 6 & $\begin{array}{l}\text { Prednisolone, } \\
\text { dexamethasone, or } \\
\text { methylprednisolone }\end{array}$ & $\begin{array}{l}\text { Rhino-orbital } \\
\text { mucormycosis } \\
\text { (Mucor spp.) }\end{array}$ & $\begin{array}{l}\text { Five patients developed } \\
\text { mucormycosis after } \\
\text { treatment with } \\
\text { corticosteroids. Mean } \\
\text { duration between } \\
\text { diagnosis of COVID-19 } \\
\text { and development of } \\
\text { symptoms of mucor was } \\
15.6 \pm 9.6 \text { (3-42) days }\end{array}$ & Type 2 diabetes & Sen et al. [68] \\
\hline Retrospective & Chicago, USA & 111 & Tocilizumab & $\begin{array}{l}\text { Fungal pneumonia } \\
\text { and sinusitis }\end{array}$ & $\begin{array}{c}\text { Administration of } \\
\text { tocilizumab was } \\
\text { associated with a higher } \\
\text { risk of fungal }(p=0.112) \\
\text { infections }\end{array}$ & $\begin{array}{l}\text { Diabetes mellitus, HTA, } \\
\text { obesity COPD, } \\
\text { cardiovascular disease }\end{array}$ & Kimmig et al. [103] \\
\hline $\begin{array}{l}\text { Case control } \\
\text { study }\end{array}$ & Barcelona, Spain & $\begin{array}{c}71 \text { cases, } \\
142 \text { controls }\end{array}$ & $\begin{array}{c}\text { Tocilizumab, baricitinib, } \\
\text { anakinra, dexamethasone, } \\
\text { prednisone, } \\
\text { hydroxycortisone }\end{array}$ & $\begin{array}{l}\text { Candida spp., } \\
\text { Aspergillus spp., } \\
\text { Fusarium spp. }\end{array}$ & $\begin{array}{l}\text { Immunomodifiers did } \\
\text { not influence occurrence } \\
\text { of nosocomial infections } \\
\text { in COVID-19 patients }\end{array}$ & $\begin{array}{c}\text { Chronic liver disease, } \\
\text { obesity, smoking, } \\
\text { invasive mechanical } \\
\text { ventilation, } \\
\text { hydroxychloroquine }\end{array}$ & Meira et al. [108] \\
\hline
\end{tabular}

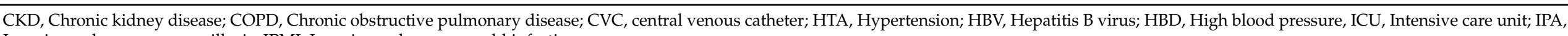
Invasive pulmonary aspergillosis; IPMI, Invasive pulmonary mold infections. 
It should also be noted that the correlation between corticosteroid use and incidence of fungal infections in hospitalized COVID-19 patients may be masked by other co-founding risk factors for fungal infections, such as the patient's history of pulmonary disease, comorbidities and mechanical ventilation [7,109]. For example, in the multicenter study by White et al. [7], apart from corticosteroid use, a history of chronic respiratory disease significantly increased the likelihood of aspergillosis. Importantly, with the exception of the study by Ho et al. [104], most of the currently reported investigations on the potential role between immunosuppressants and fungal infections are from a small cohort of patients. Such a small study size lacks sufficient statistical power and may consequently lead to false conclusions. Indeed, thorough metanalyses of additional retrospective and randomized control studies will help elucidate the role of immunosuppressants in predisposing COVID-19 patients to fungal co-infections.

\section{Conclusions}

Fungal co-infections are reported in severely ill COVID-19 patients admitted to the ICU, with a higher rate of incidence for aspergillosis followed by candidemia, as observed from our literature analysis. Risk factors for such fungal co-infections in the ICU are related to host factors, medical procedures and therapeutics such as corticosteroids, which are designed to alleviate the COVID-19 disease condition. Thus, the links between fungal infections and higher mortality rates in COVID-19 patients and between treatment options and fungal infections provide a conundrum that challenges current medical practices to develop innovative strategies for limiting secondary nosocomial fungal infections in the hospital setting. However, in the interim, prompt diagnosis of fungal co-infections and antifungal administration may help improve prognosis in hospitalized COVID-19 patients.

Supplementary Materials: The following are available online at https:/ /www.mdpi.com/article/10 .3390 /jof7070545/s1, Table S1: Bibliographic and geographical information of studies analyzed in Figure 1.

Author Contributions: Conceptualization, C.H.P. and O.G.; methodology, C.H.P.; formal analysis, O.T.E.; investigation, O.T.E., O.G. and C.H.P.; resources, C.H.P.; data curation, O.T.E.;writing-original draft preparation, O.T.E.; writing-review and editing, C.H.P. and O.G.; supervision, C.H.P.; funding acquisition, C.H.P. All authors have read and agreed to the published version of the manuscript.

Funding: This research was funded by the National Research Foundation (NRF) of South Africa, grant number 115566. C.H.P. holds an NRF SARChI Research Chair in Pathogenic Yeasts.

Institutional Review Board Statement: Not applicable.

Informed Consent Statement: Not applicable.

Data Availability Statement: Supporting data for Figure 1 is in the supplementary information.

Conflicts of Interest: The authors declare no conflict of interest.

\section{References}

1. Worldometers. COVID Live Update. Available online: https://www.worldometers.info/coronavirus/ (accessed on 23 June 2021).

2. WHO. Coronavirus Disease (COVID-19). Available online: https://www.who.int/emergencies/diseases/novel-coronavirus-2019 (accessed on 21 May 2021).

3. Ezeokoli, O.T.; Pohl, C.H. Opportunistic pathogenic fungal co-infections are prevalent in critically ill COVID-19 patients: Are they risk factors for disease severity? S. Afr. Med. J. 2020, 110, 1081-1085. [CrossRef]

4. Song, G.; Liang, G.; Liu, W. Fungal Co-infections Associated with Global COVID-19 Pandemic: A Clinical and Diagnostic Perspective from China. Mycopathologia 2020, 185, 599-606. [CrossRef] [PubMed]

5. Salmanton-García, J.; Sprute, R.; Stemler, J.; Bartoletti, M.; Dupont, D.; Valerio, M.; Garcia-Vidal, C.; Falces-Romero, I.; Machado, M.; de la Villa, S.; et al. COVID-19-associated pulmonary aspergillosis, March-August 2020. Emerg. Infect. Dis. 2021, 27, 1077-1086. [CrossRef] [PubMed]

6. $\quad$ Bartoletti, M.; Pascale, R.; Cricca, M.; Rinaldi, M.; Maccaro, A.; Bussini, L.; Fornaro, G.; Tonetti, T.; Pizzilli, G.; Francalanci, E.; et al. Epidemiology of Invasive Pulmonary Aspergillosis Among Intubated Patients With COVID-19: A Prospective Study. Clin. Infect. Dis. 2020. [CrossRef] [PubMed] 
7. White, P.L.; Dhillon, R.; Cordey, A.; Hughes, H.; Faggian, F.; Soni, S.; Pandey, M.; Whitaker, H.; May, A.; Morgan, M.; et al. A National Strategy to Diagnose Coronavirus Disease 2019-Associated Invasive Fungal Disease in the Intensive Care Unit. Clin. Infect. Dis. 2020, 1-11. [CrossRef]

8. Katz, J. Prevalence of candidiasis and oral candidiasis in COVID-19 patients: A cross-sectional pilot study from the patients registry in a large health center. Quintessence Int. 2021. [CrossRef]

9. Nucci, M.; Barreiros, G.; Guimarães, L.F.; Deriquehem, V.A.S.; Castiñeiras, A.C.; Nouér, S.A. Increased incidence of candidemia in a tertiary care hospital with the COVID-19 pandemic. Mycoses 2021, 64, 152-156. [CrossRef]

10. Ahmadi, A.; Ardehali, S.H.; Beigmohammadi, M.T.; Hajiabdolbaghi, M.; Hashemian, S.M.R.; Kouchek, M.; Majidpour, A.; Mokhtari, M.; Moghaddam, O.M.; Najafi, A. Invasive candidiasis in intensive care unit; consensus statement from an Iranian panel of experts, July 2013. JRSM Open 2014, 5, 1-10. [CrossRef]

11. Hwang, D.M.; Chamberlain, D.W.; Poutanen, S.M.; Low, D.E.; Asa, S.L.; Butany, J. Pulmonary pathology of severe acute respiratory syndrome in Toronto. Mod. Pathol. 2005, 18, 1-10. [CrossRef]

12. Schauwvlieghe, A.F.A.D.; Rijnders, B.J.A.; Philips, N.; Verwijs, R.; Vanderbeke, L.; Van Tienen, C.; Lagrou, K.; Verweij, P.E.; Van de Veerdonk, F.L.; Gommers, D.; et al. Invasive aspergillosis in patients admitted to the intensive care unit with severe influenza: A retrospective cohort study. Lancet Respir. Med. 2018, 6, 782-792. [CrossRef]

13. Prattes, J.; Valentin, T.; Hoenigl, M.; Talakic, E.; Reisinger, A.C.; Eller, P. Invasive pulmonary aspergillosis complicating COVID-19 in the ICU-A case report. Med. Mycol. Case Rep. 2021, 31, 2-5. [CrossRef]

14. Menon, A.A.; Berg, D.D.; Brea, E.J.; Deutsch, A.J.; Kidia, K.K.; Thurber, E.G.; Polsky, S.B.; Yeh, T.; Duskin, J.A.; Holliday, A.M.; et al. A case of COVID-19 and Pneumocystis jirovecii coinfection. Am. J. Respir. Crit. Care Med. 2020, 202, 136-138. [CrossRef]

15. Salehi, M.; Ahmadikia, K.; Mahmoudi, S.; Kalantari, S.; Jamalimoghadam Siahkali, S.; Izadi, A.; Kord, M.; Dehghan Manshadi, S.A.; Seifi, A.; Ghiasvand, F. Oropharyngeal candidiasis in hospitalized COVID-19 Patients from Iran: Species identification and antifungal susceptibility pattern. Mycoses 2020. [CrossRef]

16. Zhu, X.; Ge, Y.; Wu, T.; Zhao, K.; Chen, Y.; Wu, B.; Zhu, F.; Zhu, B.; Cui, L. Co-infection with respiratory pathogens among COVID-2019 cases. Virus Res. 2020, 285. [CrossRef]

17. He, Y.; Li, W.; Wang, Z.; Chen, H.; Tian, L.; Liu, D. Nosocomial infection among patients with COVID-19: A retrospective data analysis of 918 cases from a single center in Wuhan, China. Infect. Control Hosp. Epidemiol. 2020, 41, 982-983. [CrossRef] [PubMed]

18. Hughes, S.; Troise, O.; Donaldson, H.; Mughal, N.; Moore, L.S.P. Bacterial and fungal coinfection among hospitalized patients with COVID-19: A retrospective cohort study in a UK secondary-care setting. Clin. Microbiol. Infect. 2020, 26, 1395-1399. [CrossRef]

19. Poignon, C.; Blaize, M.; Vezinet, C.; Lampros, A.; Monsel, A.; Fekkar, A. Invasive pulmonary fusariosis in an immunocompetent critically ill patient with severe COVID-19. Clin. Microbiol. Infect. 2020, 26, 1582-1584. [CrossRef]

20. Ahmadikia, K.; Hashemi, S.J.; Khodavaisy, S.; Getso, M.I.; Alijani, N.; Badali, H.; Mirhendi, H.; Salehi, M.; Tabari, A.; Mohammadi Ardehali, M.; et al. The double-edged sword of systemic corticosteroid therapy in viral pneumonia: A case report and comparative review of influenza-associated mucormycosis versus COVID-19 associated mucormycosis. Mycoses 2021. [CrossRef]

21. Signorini, L.; Moioli, G.; Calza, S.; Van Hauwermeiren, E.; Lorenzotti, S.; Del Fabro, G.; Renisi, G.; Lanza, P.; Saccani, B.; Zambolin, G.; et al. Epidemiological and Clinical Characterization of Superinfections in Critically Ill Coronavirus Disease 2019 Patients. Crit. Care Explor. 2021, 3, e0430. [CrossRef] [PubMed]

22. Chen, N.; Zhou, M.; Dong, X.; Qu, J.; Gong, F.; Han, Y.; Qiu, Y.; Wang, J.; Liu, Y.; Wei, Y.; et al. Epidemiological and clinical characteristics of 99 cases of 2019 novel coronavirus pneumonia in Wuhan, China: A descriptive study. Lancet 2020, 395, 507-513. [CrossRef]

23. Gerver, S.M.; Guy, R.; Wilson, K.; Thelwall, S.; Nsonwu, O.; Rooney, G.; Brown, C.S.; Muller-Pebody, B.; Hope, R.; Hall FFPH, V. National surveillance of bacterial and fungal co- and secondary infection in COVID-19 patients in England-Lessons from the first wave. Clin. Microbiol. Infect. 2021. [CrossRef]

24. Du, Y.; Tu, L.; Zhu, P.; Mu, M.; Wang, R.; Yang, P.; Wang, X.; Hu, C.; Ping, R.; Hu, P.; et al. Clinical features of 85 fatal cases of COVID-19 from Wuhan: A retrospective observational study. Am. J. Respir. Crit. Care Med. 2020, 201, 1372-1379. [CrossRef]

25. Villanueva-Lozano, H.; Treviño-Rangel, R.d.J.; González, G.M.; Ramírez-Elizondo, M.T.; Lara-Medrano, R.; Aleman-Bocanegra, M.C.; Guajardo-Lara, C.E.; Gaona-Chávez, N.; Castilleja-Leal, F.; Torre-Amione, G.; et al. Outbreak of Candida auris infection in a COVID-19 hospital in Mexico. Clin. Microbiol. Infect. 2021, 27, 813. [CrossRef] [PubMed]

26. Chowdhary, A.; Tarai, B.; Singh, A.; Sharma, A. Multidrug-Resistant Candida auris Infections in Critically Ill Coronavirus Disease Patients, India, April-July 2020. Emerg. Infect. Dis. 2020, 26, 2694-2696. [CrossRef] [PubMed]

27. Magnasco, L.; Mikulska, M.; Giacobbe, D.R.; Taramasso, L.; Vena, A.; Dentone, C.; Dettori, S.; Tutino, S.; Labate, L.; Di Pilato, V.; et al. Spread of carbapenem-resistant gram-negatives and Candida auris during the COVID-19 pandemic in critically ill patients: One step back in antimicrobial stewardship? Microorganisms 2021, 9, 95. [CrossRef]

28. Rodriguez, J.Y.; Le Pape, P.; Lopez, O.; Esquea, K.; Labiosa, A.L.; Alvarez-Moreno, C. Candida auris: A Latent Threat to Critically Ill Patients With Coronavirus Disease 2019. Clin. Infect. Dis. 2020. [CrossRef] [PubMed]

29. Al-Hatmi, A.M.S.M.; Mohsin, J.; Al-Huraizi, A.; Khamis, F. COVID-19 associated invasive candidiasis. J. Infect. 2021, 82, e45-e46. [CrossRef] [PubMed]

30. De Almeida, J.N.; Francisco, E.C.; Hagen, F.; Brandão, I.B.; Pereira, F.M.; Presta Dias, P.H.; de Miranda Costa, M.M.; de Souza Jordão, R.T.; de Groot, T.; Colombo, A.L. Emergence of Candida auris in brazil in a covid-19 intensive care unit. J. Fungi 2021, 7, 220. [CrossRef] [PubMed] 
31. Arastehfar, A.; Shaban, T.; Zarrinfar, H.; Roudbary, M.; Ghazanfari, M.; Hedayati, M.-T.; Sedaghat, A.; Ilkit, M.; Najafzadeh, M.J.; Perlin, D.S. Candidemia among Iranian Patients with Severe COVID-19 Admitted to ICUs. J. Fungi 2021, 7, 280. [CrossRef]

32. Meijer, E.F.J.; Dofferhoand, A.S.M.; Meis, J.F.; Hoiting, O.; Buil, J.B. Azole-resistant COVID-19-associated pulmonary aspergillosis in an immunocompetent host: A case report. J. Fungi 2020, 6, 79. [CrossRef]

33. Blaize, M.; Mayaux, J.; Nabet, C.; Nabet, C.; Lampros, A.; Marcelin, A.G.; Marcelin, A.G.; Thellier, M.; Thellier, M.; Piarroux, R.; et al. Fatal Invasive Aspergillosis and Coronavirus Disease in an Immunocompetent Patient. Emerg. Infect. Dis. 2020, 26, 1636-1637. [CrossRef] [PubMed]

34. Antinori, S.; Bonazzetti, C.; Gubertini, G.; Capetti, A.; Pagani, C.; Morena, V.; Rimoldi, S.; Galimberti, L.; Sarzi-Puttini, P.; Ridolfo, A.L. Tocilizumab for cytokine storm syndrome in COVID-19 pneumonia: An increased risk for candidemia? Autoimmun. Rev. 2020, 19, 102564. [CrossRef] [PubMed]

35. Lahmer, T.; Kriescher, S.; Herner, A.; Rothe, K.; Spinner, C.D.; Schneider, J.; Mayer, U.; Neuenhahn, M.; Hoffmann, D.; Geisler, F.; et al. Invasive pulmonary aspergillosis in critically ill patients with severe COVID-19 pneumonia: Results from the prospective AspCOVID-19 study. PLoS ONE 2021, 16, e0238825. [CrossRef] [PubMed]

36. Benedetti, M.F.; Alava, K.H.; Sagardia, J.; Cadena, R.C.; Laplume, D.; Capece, P.; Posse, G.; Nusblat, A.D.; Cuestas, M.L. COVID-19 associated pulmonary aspergillosis in ICU patients: Report of five cases from Argentina. Med. Mycol. Case Rep. 2021, 31, 24-28. [CrossRef]

37. Alobaid, K.; Yousuf, B.; Al-Qattan, E.; Muqeem, Z.; Al-Subaie, N. Pulmonary aspergillosis in two COVID-19 patients from Kuwait. Access Microbiol. 2021, 3. [CrossRef]

38. Meijer, E.F.J.; Dofferhoff, A.S.M.; Hoiting, O.; Meis, J.F. COVID-19-associated pulmonary aspergillosis: A prospective single-center dual case series. Mycoses 2021, 64, 457-464. [CrossRef]

39. Savi, D.; Valente, G.; Iacovelli, A.; Olmati, F.; Bezzi, M.; Palange, P. Uncommon presentation of allergic bronchopulmonary aspergillosis during the COVID-19 lockdown: A case report. BMC Pulm. Med. 2020, 20, 325. [CrossRef]

40. Cataldo, M.A.; Tetaj, N.; Selleri, M.; Marchioni, L.; Capone, A.; Caraffa, E.; Caro, A.D.; Petrosillo, N. Incidence of bacterial and fungal bloodstream infections in COVID-19 patients in intensive care: An alarming "collateral effect". J. Glob. Antimicrob. Resist. 2020, 23, 290-291. [CrossRef]

41. Didbaridze, T.; Ratiani, L.; Labadze, N.; Maziashvili, T.; Didbaridze, N.; Gogokhia, N. Prevalence and Prognosis of Candidiasis among Covid-19 Patients: Data from ICU Department. Int. J. Progress. Sci. Technol. 2021, 26, 36-39.

42. Alataby, H.; Atemnkeng, F.; Bains, S.S.; Kenne, F.M.; Diaz, K.; Nfonoyim, J. A COVID-19 Case Complicated by Candida dubliniensis and Klebsiella pneumoniae-Carbapenem-Resistant Enterobacteriaceae. J. Med. Cases 2020, 11, 403-406. [CrossRef] [PubMed]

43. Sari, A.P.; Darnindro, N.; Yohanes, A.; Mokoagow, M.I. Role of tocilizumab for concomitant systemic fungal infection in severe COVID-19 patient: Case report. Medicine 2021, 100, e25173. [CrossRef] [PubMed]

44. Lescure, F.X.; Bouadma, L.; Nguyen, D.; Parisey, M.; Wicky, P.H.; Behillil, S.; Gaymard, A.; Bouscambert-Duchamp, M.; Donati, F.; Le Hingrat, Q.; et al. Clinical and virological data of the first cases of COVID-19 in Europe: A case series. Lancet Infect. Dis. 2020, 20, 697-706. [CrossRef]

45. Burgos Santamaría, A.; Lema, T.M.; Pizarro, C.A.G. Invasive pulmonary aspergillosis in COVID-19. A case series at Gregorio Maranon University General Hospital. Rev. Chil. Anest. 2021. [CrossRef]

46. De Almeida, J.N.; Moreno, L.; Francisco, E.C.; Marques, G.N.; Mendes, A.V.; Barberino, M.G.; Colombo, A.L. Trichosporon asahii superinfections in critically ill COVID-19 patients overexposed to antimicrobials and corticosteroids. Mycoses 2021. [CrossRef]

47. Patti, R.K.; Dalsania, N.R.; Somal, N.; Sinha, A.; Mehta, S.; Ghitan, M.; Seneviratne, C.; Kupfer, Y. Subacute Aspergillosis “Fungal Balls" Complicating COVID-19. J. Investig. Med. High Impact Case Rep. 2020, 8. [CrossRef]

48. Vélez Pintado, M.; Camiro-Zúñiga, A.; Aguilar Soto, M.; Cuenca, D.; Mercado, M.; Crabtree-Ramirez, B. COVID-19-associated invasive pulmonary aspergillosis in a tertiary care center in Mexico City. Med. Mycol. 2021, 1-6. [CrossRef]

49. Dupont, D.; Menotti, J.; Turc, J.; Miossec, C.; Wallet, F.; Richard, J.C.; Argaud, L.; Paulus, S.; Wallon, M.; Ader, F.; et al. Pulmonary aspergillosis in critically ill patients with Coronavirus Disease 2019 (Covid-19). Med. Mycol. 2021, 59, 110-114. [CrossRef]

50. Rutsaert, L.; Steinfort, N.; Van Hunsel, T.; Bomans, P.; Naesens, R.; Mertes, H.; Dits, H.; Van Regenmortel, N. COVID-19-associated invasive pulmonary aspergillosis. Ann. Intensive Care 2020, 10, 71. [CrossRef]

51. Albasata, H.; Alamri, M.M.; Almuhaidb, S.A.; Aljebreen, A.M.; Almaghrabia, R.S. Case Report: Diagnostic challenge of COVID-19 associated pulmonary aspergillosis (CAPA). F1000Research 2021, 10, 59. [CrossRef]

52. Alanio, A.; Dellière, S.; Fodil, S.; Bretagne, S.; Mégarbane, B. Prevalence of putative invasive pulmonary aspergillosis in critically ill patients with COVID-19. Lancet Respir. Med. 2020, 8, e48-e49. [CrossRef]

53. Van Arkel, A.L.E.; Rijpstra, T.A.; Belderbos, H.N.A.; van Wijngaarden, P.; Verweij, P.E.; Bentvelsen, R.G. COVID-19-associated pulmonary aspergillosis. Am. J. Respir. Crit. Care Med. 2020, 202, 132-135. [CrossRef] [PubMed]

54. Sharma, A.; Hofmeyr, A.; Bansal, A.; Thakkar, D.; Lam, L.; Harrington, Z.; Bhonagiri, D. COVID-19 associated pulmonary aspergillosis (CAPA): An Australian case report. Med. Mycol. Case Rep. 2021, 31, 6-10. [CrossRef]

55. Santana, M.F.; Pivoto, G.; Alexandre, M.A.A.; Baía-Da-silva, D.C.; Borba, M.G.d.S.; Val, F.A.; Brito-Sousa, J.D.; Melo, G.C.; Monteiro, W.M.; Souza, J.V.B.; et al. Confirmed invasive pulmonary aspergillosis and COVID-19: The value of postmortem findings to support antemortem management. Rev. Soc. Bras. Med. Trop. 2020, 53, 1-4. [CrossRef] [PubMed] 
56. Mohamed, A.; Hassan, T.; Trzos-Grzybowska, M.; Thomas, J.; Quinn, A.; O’Sullivan, M.; Griffin, A.; Rogers, T.R.; Talento, A.F. Multi-triazole-resistant Aspergillus fumigatus and SARS-CoV-2 co-infection: A lethal combination. Med. Mycol. Case Rep. 2021, 31, 11-14. [CrossRef] [PubMed]

57. Mastrangelo, A.; Germinario, B.N.; Ferrante, M.; Frangi, C.; Li Voti, R.; Muccini, C.; Ripa, M.; Canetti, D.; Castiglioni, B.; Oltolini, C.; et al. Candidemia in Coronavirus Disease 2019 (COVID-19) Patients: Incidence and Characteristics in a Prospective Cohort Compared With Historical Non-COVID-19 Controls. Clin. Infect. Dis. 2020. [CrossRef]

58. Kuehn, B.M. Drug-Resistant Yeast Infections Spread in COVID-19 Unit. JAMA 2021, 325, 714. [CrossRef] [PubMed]

59. Posteraro, B.; Torelli, R.; Vella, A.; Leone, P.M.; De Angelis, G.; De Carolis, E.; Ventura, G.; Sanguinetti, M.; Fantoni, M. Panechinocandin-resistant Candida glabrata bloodstream infection complicating COVID-19: A fatal case report. J. Fungi 2020, 6, 163. [CrossRef] [PubMed]

60. Konopka, J.B.; Casadevall, A.; Taylor, J.W.; Heitman, J.; Cowen, L. One Health: Fungal Pathogens of Humans, Animals, and Plants; American Society for Microbiology: Washington, DC, USA, 2019.

61. Fisher, M.C.; Hawkins, N.J.; Sanglard, D.; Gurr, S.J. Worldwide emergence of resistance to antifungal drugs challenges human health and food security. Science 2018, 360, 739-742. [CrossRef]

62. Morales-López, S.E.; Parra-Giraldo, C.M.; Ceballos-Garzón, A.; Martínez, H.P.; Rodríguez, G.J.; Álvarez-Moreno, C.A.; Rodríguez, J.Y. Invasive infections with multidrug-resistant yeast Candida auris, Colombia. Emerg. Infect. Dis. 2017, 23, 162-164. [CrossRef]

63. Forsberg, K.; Woodworth, K.; Walters, M.; Berkow, E.L.; Jackson, B.; Chiller, T.; Vallabhaneni, S. Candida auris: The recent emergence of a multidrug-resistant fungal pathogen. Med. Mycol. 2019, 57, 1-12. [CrossRef]

64. Ademe, M.; Girma, F. Candida auris: From multidrug resistance to pan-resistant strains. Infect. Drug Resist. 2020, 13, 1287-1294. [CrossRef]

65. Suarez-de-la-Rica, A.; Serrano, P.; de-la-Oliva, R.; Sánchez-Díaz, P.; Molinero, P.; Falces-Romero, I.; Ferrando, C.; Rello, J.; Maseda, E. Secondary infections in mechanically ventilated patients with COVID-19: An overlooked matter? Rev. Esp. Quimioter. 2021. [CrossRef] [PubMed]

66. Biswas, S. Mucormycosis: The “Black Fungus” Maiming Covid Patients in India. Available online: https://www.bbc.com/news / world-asia-india-57027829 (accessed on 9 May 2021).

67. At Least 8 Covid Survivours Die of Black Fungus "Mucormycosis" in Maharashtra. Available online: https://theprint.in/health/ at-least-8-covid-survivors-die-of-black-fungus-mucormycosis-in-maharashtra/654924/ (accessed on 9 May 2021).

68. Sen, M.; Lahane, S.; Lahane, T.P.; Parekh, R.; Honavar, S.G. Mucor in a Viral Land: A Tale of Two Pathogens. Indian J. Ophthalmol. 2021, 69, 244-252. [CrossRef]

69. Sharma, S.; Grover, M.; Bhargava, S.; Samdani, S.; Kataria, T. Post coronavirus disease mucormycosis: A deadly addition to the pandemic spectrum. J. Laryngol. Otol. 2021, 135, 442-447. [CrossRef] [PubMed]

70. Chikley, A.; Ben-Ami, R.; Kontoyiannis, D.P. Mucormycosis of the central nervous system. J. Fungi 2019, 5, 59. [CrossRef] [PubMed]

71. Dusart, A.; Duprez, T.; Van Snick, S.; Godfraind, C.; Sindic, C. Fatal rhinocerebral mucormycosis with intracavernous carotid aneurysm and thrombosis: A late complication of transsphenoidal surgery? Acta Neurol. Belg. 2013, 113, 179-184. [CrossRef]

72. Sarkar, S.; Gokhale, T.; Choudhury, S.; Deb, A. COVID-19 and orbital mucormycosis. Indian J. Ophthalmol. 2021, 69, 1002-1004. [CrossRef]

73. Prakash, H.; Chakrabarti, A. Epidemiology of mucormycosis in India. Microorganisms 2021, 9, 523. [CrossRef]

74. Zurl, C.; Hoenigl, M.; Schulz, E.; Hatzl, S.; Gorkiewicz, G.; Krause, R.; Eller, P.; Prattes, J. Autopsy proven pulmonary mucormycosis due to Rhizopus microsporus in a critically Ill COVID-19 patient with underlying hematological malignancy. J. Fungi 2021, 7, 88. [CrossRef]

75. CDC (Centers for Disease Control and Prevention). Mucormycosis. Available online: https://www.cdc.gov/fungal/diseases/ mucormycosis/index.html (accessed on 11 May 2021).

76. Singh, A.K.; Singh, R.; Joshi, S.R.; Misra, A. Mucormycosis in COVID-19: A systematic review of cases reported worldwide and in India. Diabetes Metab. Syndr. Clin. Res. Rev. 2021. [CrossRef]

77. Mulakavalupil, B.; Vaity, C.; Joshi, S.; Misra, A.; Pandit, R.A. Absence of Case of Mucormycosis (March 2020-May 2021) under strict protocol driven management care in a COVID-19 specific tertiary care intensive care unit. Diabetes Metab. Syndr. Clin. Res. Rev. 2021. [CrossRef]

78. Garg, D.; Muthu, V.; Sehgal, I.S.; Ramachandran, R.; Kaur, H.; Bhalla, A.; Puri, G.D.; Chakrabarti, A.; Agarwal, R. Coronavirus Disease (Covid-19) Associated Mucormycosis (CAM): Case Report and Systematic Review of Literature. Mycopathologia 2021, 186, 289-298. [CrossRef] [PubMed]

79. Cultrera, R.; Barozzi, A.; Libanore, M.; Marangoni, E.; Pora, R.; Quarta, B.; Spadaro, S.; Ragazzi, R.; Marra, A.; Segala, D.; et al. Co-infections in critically ill patients with or without covid-19: A comparison of clinical microbial culture findings. Int. J. Environ. Res. Public Health 2021, 18, 4358. [CrossRef] [PubMed]

80. Arastehfar, A.; Carvalho, A.; van de Veerdonk, F.L.; Jenks, J.D.; Koehler, P.; Krause, R.; Cornely, O.A.; Perlin, D.S.; Lass-Flörl, C.; Hoenigl, M. COVID-19 associated pulmonary aspergillosis (CAPA)_From immunology to treatment. J. Fungi $2020,6,91$. [CrossRef] 
81. Arastehfar, A.; Carvalho, A.; Hong Nguyen, M.; Hedayati, M.T.; Netea, M.G.; Perlin, D.S.; Hoenigl, M. Covid-19-associated candidiasis (Cac): An underestimated complication in the absence of immunological predispositions? J. Fungi 2020, 6, 211. [CrossRef]

82. Riche, C.V.W.; Cassol, R.; Pasqualotto, A.C. Is the frequency of candidemia increasing in covid-19 patients receiving corticosteroids? J. Fungi 2020, 6, 286. [CrossRef]

83. Koehler, P.; Bassetti, M.; Chakrabarti, A.; Chen, S.C.A.; Colombo, A.L.; Hoenigl, M.; Klimko, N.; Lass-Flörl, C.; Oladele, R.O.; Vinh, D.C.; et al. Defining and managing COVID-19-associated pulmonary aspergillosis: The 2020 ECMM/ISHAM consensus criteria for research and clinical guidance. Lancet Infect. Dis. 2021, 3099. [CrossRef]

84. Verweij, P.E.; Rijnders, B.J.A.; Brüggemann, R.J.M.; Azoulay, E.; Bassetti, M.; Blot, S.; Calandra, T.; Clancy, C.J.; Cornely, O.A.; Chiller, T.; et al. Review of influenza-associated pulmonary aspergillosis in ICU patients and proposal for a case definition: An expert opinion. Intensive Care Med. 2020, 46, 1524-1535. [CrossRef]

85. Tolle, L.B.; Standiford, T.J. Danger-associated molecular patterns (DAMPs) in acute lung injury. J. Pathol. 2013, 229, 145-156. [CrossRef]

86. Singh, G.; Pitoyo, C.W.; Aditianingsih, D.; Rumende, C.M. Risk factors for early invasive fungal disease in critically ill patients. Indian J. Crit. Care Med. 2016, 20, 633-639. [CrossRef]

87. Chakraborti, A.; Jaiswal, A.; Verma, P.; Singhal, R. A prospective study of fungal colonization and invasive fungal disease in long-term mechanically ventilated patients in a respiratory intensive care unit. Indian J. Crit. Care Med. 2018, $22,597-601$. [CrossRef] [PubMed]

88. Dellière, S.; Dudoignon, E.; Fodil, S.; Voicu, S.; Collet, M.; Oillic, P.A.; Salmona, M.; Dépret, F.; Ghelfenstein-Ferreira, T.; Plaud, B.; et al. Risk factors associated with COVID-19-associated pulmonary aspergillosis in ICU patients: A French multicentric retrospective cohort. Clin. Microbiol. Infect. 2021, 27. [CrossRef] [PubMed]

89. Venditto, V.J.; Haydar, D.; Abdel-Latif, A.; Gensel, J.C.; Anstead, M.I.; Pitts, M.G.; Creameans, J.; Kopper, T.J.; Peng, C.; Feola, D.J. Immunomodulatory Effects of Azithromycin Revisited: Potential Applications to COVID-19. Front. Immunol. 2021, 12, 574425. [CrossRef]

90. NIH (National Institute of Health). COVID-19 Treatment Guidelines. Available online: https:/ /www.covid19treatmentguidelines. nih.gov/whats-new/ (accessed on 11 May 2021).

91. Ye, Q.; Wang, B.; Mao, J. The pathogenesis and treatment of the "Cytokine Storm" in COVID-19. J. Infect. 2020, 80, 607-613. [CrossRef] [PubMed]

92. Hu, B.; Huang, S.; Yin, L. The cytokine storm and COVID-19. J. Med. Virol. 2021, 93, 250-256. [CrossRef]

93. Fajgenbaum, D.C.; June, C.H. Cytokine Storm. N. Engl. J. Med. 2020, 383, 2255-2273. [CrossRef]

94. The RECOVERY Collaborative Group. Dexamethasone in Hospitalized Patients with Covid-19. N. Engl. J. Med. 2021, 384, 693-704. [CrossRef]

95. Lewis, R.E.; Kontoyiannis, D.P. Invasive aspergillosis in glucocorticoid-treated patients. Med. Mycol. 2009, 47, 271-281. [CrossRef]

96. Lionakis, M.S.; Kontoyiannis, D.P. Glucocorticoids and invasive fungal infections. Lancet 2003, 362, 1828-1838. [CrossRef]

97. Coutinho, A.E.; Chapman, K.E. The anti-inflammatory and immunosuppressive effects of glucocorticoids, recent developments and mechanistic insights. Mol. Cell. Endocrinol. 2011, 335, 2-13. [CrossRef]

98. Oppong, E.; Cato, A.C.B. Effects of glucocorticoids in the immune system. Adv. Exp. Med. Biol. 2015, 872, 217-233. [CrossRef]

99. Armstrong-James, D.; Youngs, J.; Bicanic, T.; Abdolrasouli, A.; Denning, D.W.; Johnson, E.; Mehra, V.; Pagliuca, T.; Patel, B.; Rhodes, J.; et al. Confronting and mitigating the risk of COVID-19 associated pulmonary aspergillosis. Eur. Respir. J. 2020, 56. [CrossRef]

100. Donnelly, J.P.; Chen, S.C.; Kauffman, C.A.; Steinbach, W.J.; Baddley, J.W.; Verweij, P.E.; Clancy, C.J.; Wingard, J.R.; Lockhart, S.R.; Groll, A.H.; et al. Revision and update of the consensus definitions of invasive fungal disease from the European organization for research and treatment of cancer and the mycoses study group education and research consortium. Clin. Infect. Dis. 2020, 71, 1367-1376. [CrossRef] [PubMed]

101. Nasir, N.; Rehman, F.; Omair, S.F. Risk factors for bacterial infections in patients with moderate to severe COVID-19: A case-control study. J. Med. Virol. 2021. [CrossRef] [PubMed]

102. Gupta, S.; Wang, W.; Hayek, S.S.; Chan, L.; Mathews, K.S.; Melamed, M.L.; Brenner, S.K.; Leonberg-Yoo, A.; Schenck, E.J.; Radbel, J.; et al. Association between Early Treatment with Tocilizumab and Mortality among Critically Ill Patients with COVID-19. JAMA Intern. Med. 2021, 181, 41-51. [CrossRef]

103. Kimmig, L.M.; Wu, D.; Gold, M.; Pettit, N.N.; Pitrak, D.; Mueller, J.; Husain, A.N.; Mutlu, E.A.; Mutlu, G.M. IL-6 Inhibition in Critically Ill COVID-19 Patients Is Associated with Increased Secondary Infections. Front. Med. 2020, 7. [CrossRef] [PubMed]

104. Ho, K.S.; Narasimhan, B.; Difabrizio, L.; Rogers, L.; Bose, S.; Li, L.; Chen, R.; Sheehan, J.; El-Halabi, M.A.; Sarosky, K.; et al. Impact of corticosteroids in hospitalised COVID-19 patients. BMJ Open Respir. Res. 2021, 8, 1-8. [CrossRef] [PubMed]

105. Machado, M.; Valerio, M.; Álvarez-Uría, A.; Olmedo, M.; Veintimilla, C.; Padilla, B.; De la Villa, S.; Guinea, J.; Escribano, P.; Ruiz-Serrano, M.J.; et al. Invasive pulmonary aspergillosis in the COVID-19 era: An expected new entity. Mycoses 2021, 64, 132-143. [CrossRef] [PubMed]

106. Deana, C.; Vetrugno, L.; Bassi, F.; De Monte, A. Tocilizumab administration in COVID-19 patients: Water on the fire or gasoline? Med. Mycol. Case Rep. 2021, 31, 32-34. [CrossRef] [PubMed] 
107. Fekkar, A.; Lampros, A.; Mayaux, J.; Poignon, C.; Demeret, S.; Constantin, J.-M.; Marcelin, A.-G.E.; Monsel, A.; Luyt, C.-E.; Blaize, M. Occurrence of Invasive Pulmonary Fungal Infections in Patients with Severe COVID-19 Admitted to the ICU. Am. J. Respir. Crit. Care Med. 2021, 203, 307-317. [CrossRef]

108. Meira, F.; Moreno-García, E.; Linares, L.; Macaya, I.; Tomé, A.; Hernández-Meneses, M.; Albiach, L.; Morata, L.; Letona, L.; Bodro, M.; et al. Impact of Inflammatory Response Modifiers on the Incidence of Hospital-Acquired Infections in Patients with COVID-19. Infect. Dis. Ther. 2021. [CrossRef] [PubMed]

109. Antinori, S.; Milazzo, L.; Sollima, S.; Galli, M.; Corbellino, M. Candidemia and invasive candidiasis in adults: A narrative review. Eur. J. Intern. Med. 2016, 34, 21-28. [CrossRef] [PubMed] 